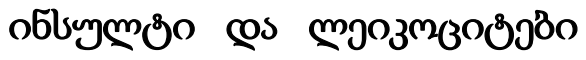

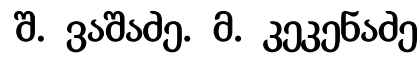

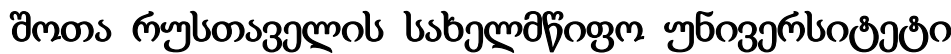

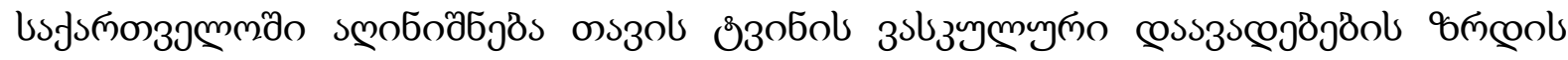

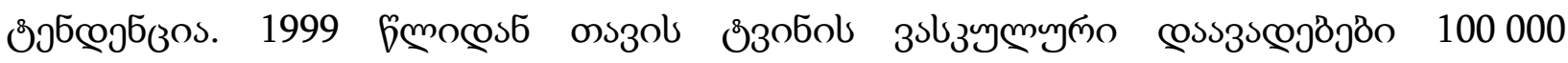

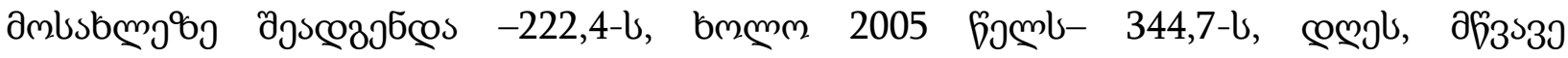

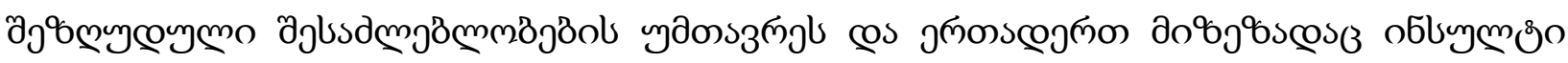

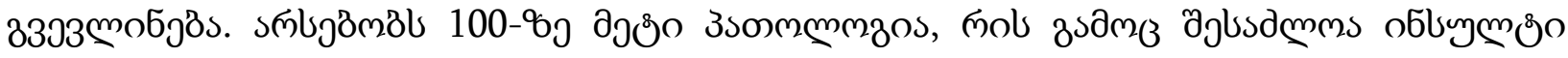

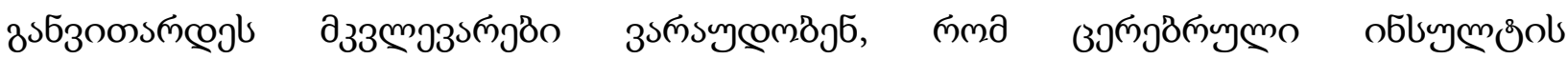

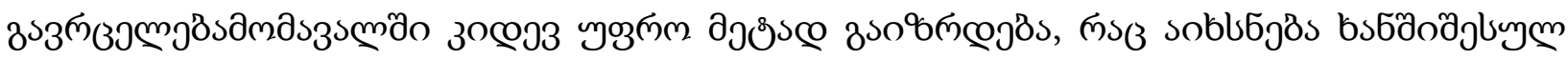

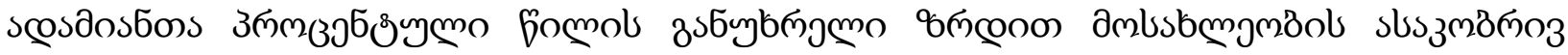

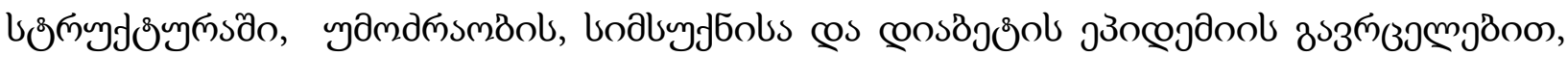

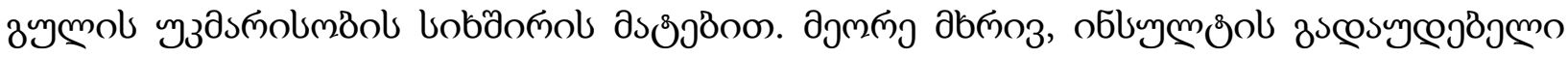

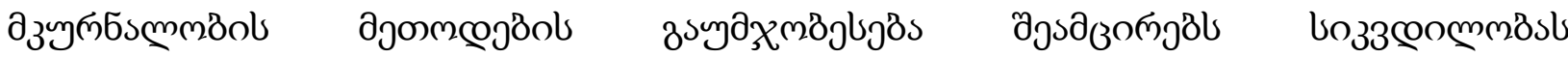

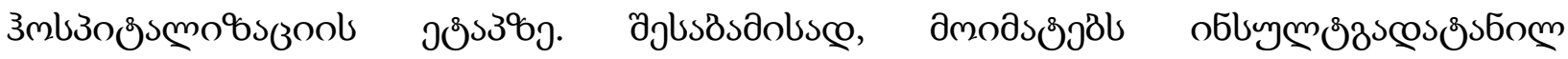

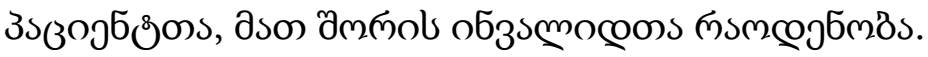

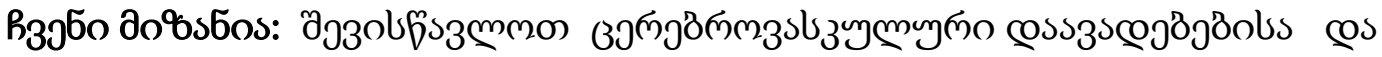

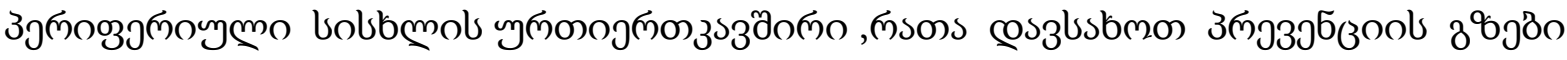

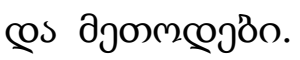

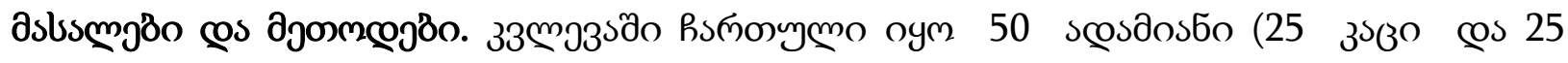

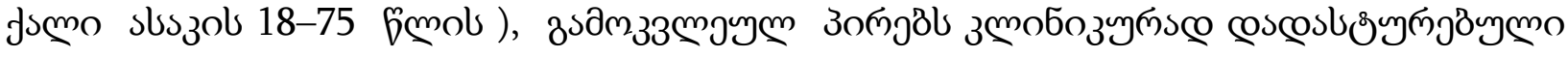

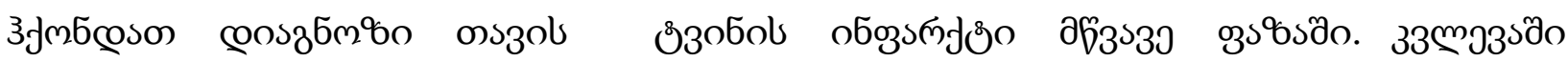

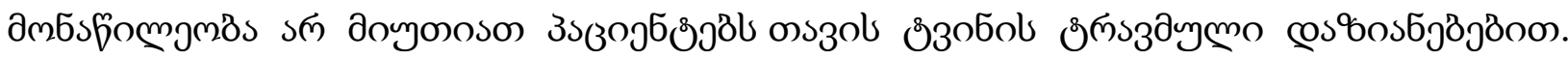

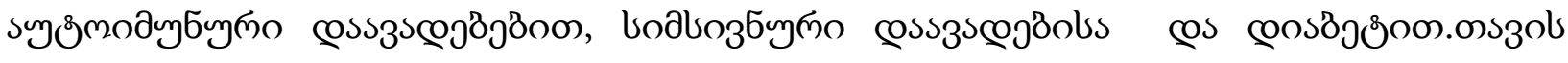

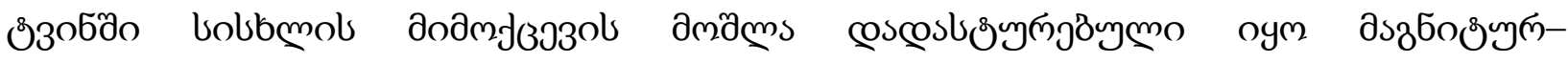

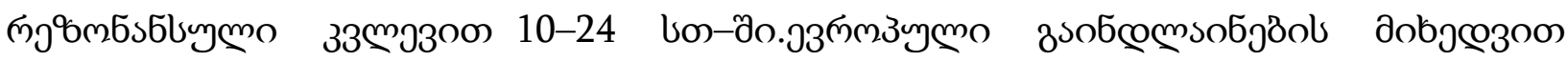

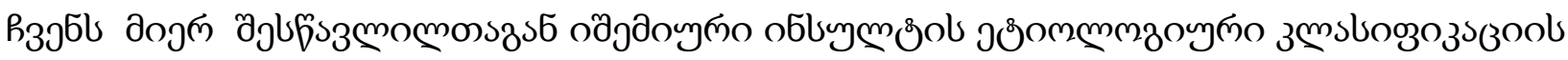

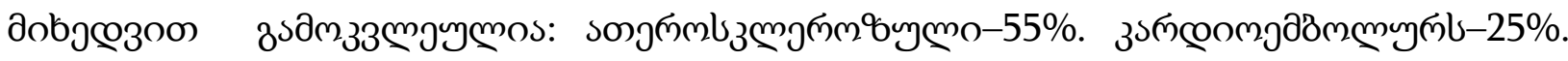




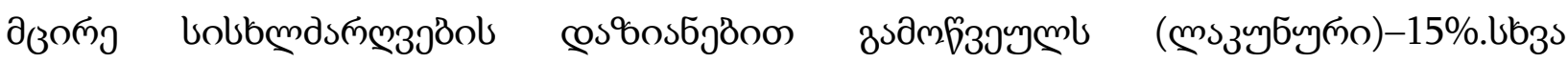

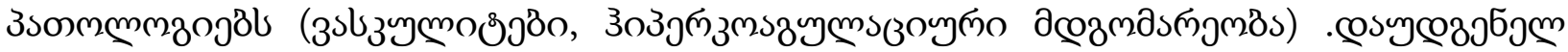
ao\%g\%ons żyoub. 5\%

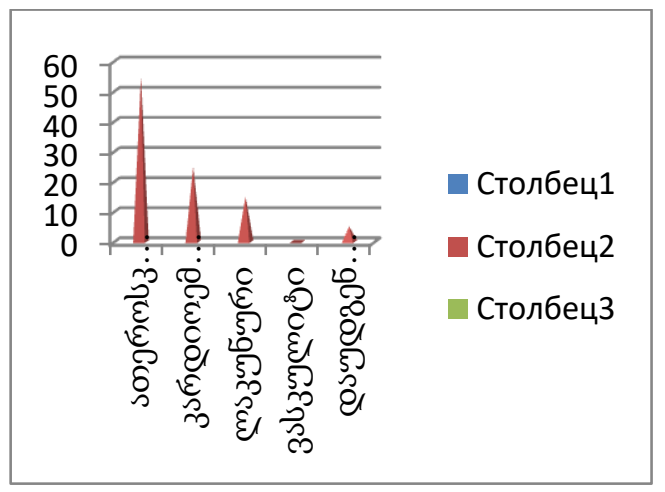

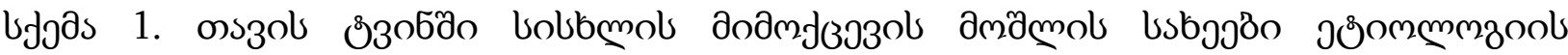
dobวœ๐on

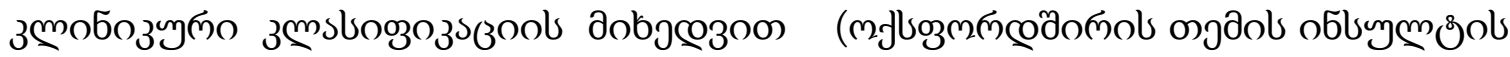

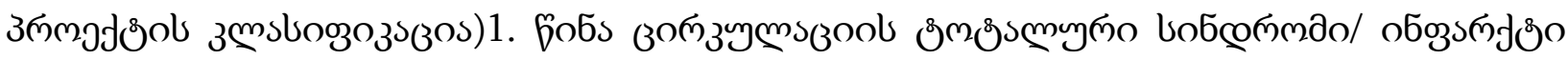

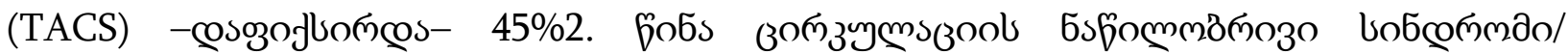

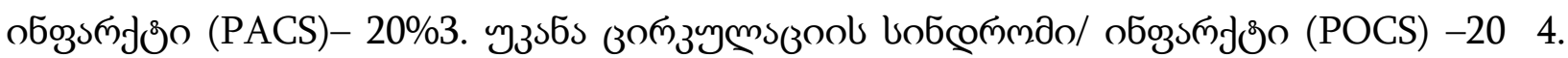

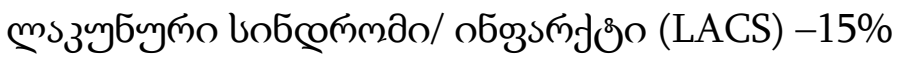

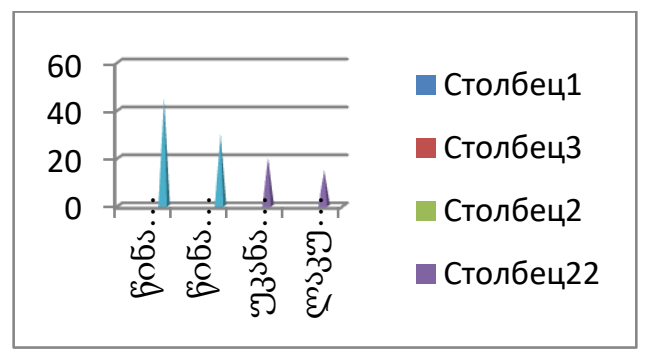

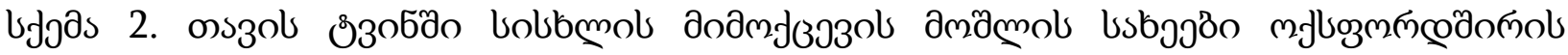

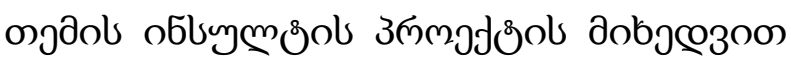

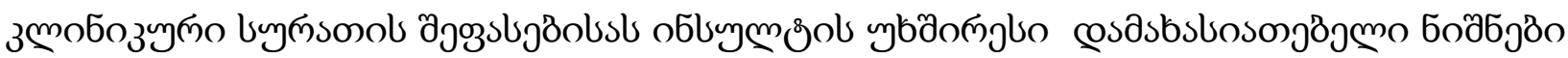

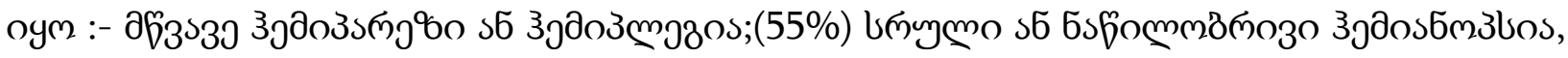

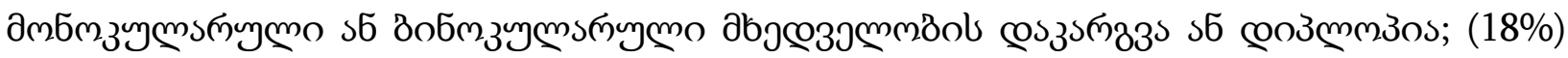

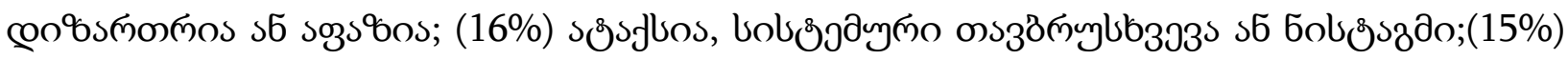




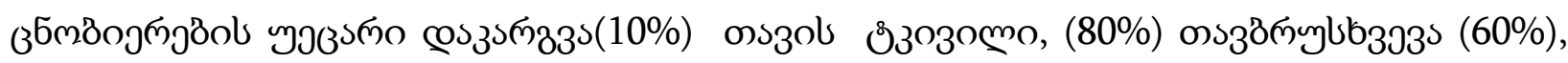

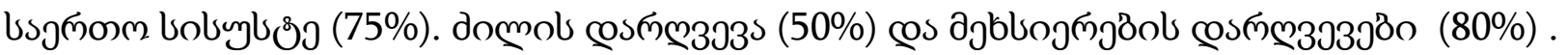

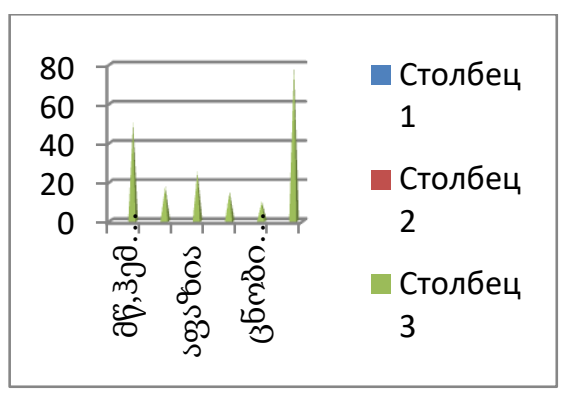

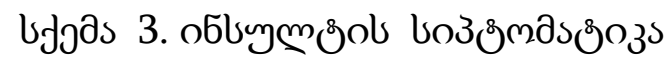

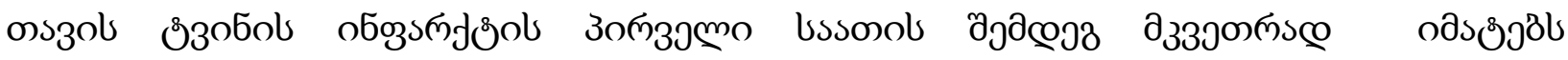

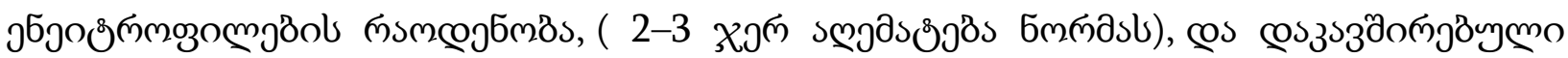

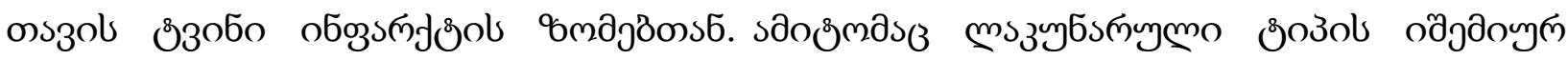

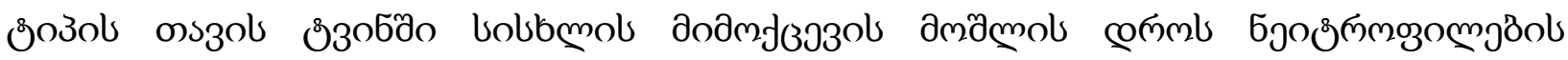

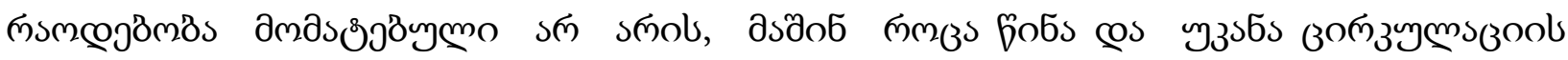

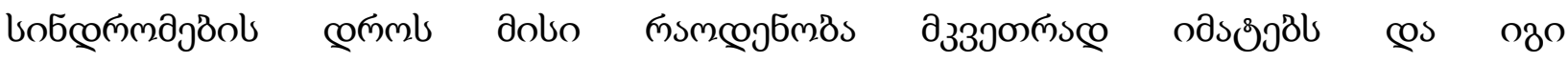

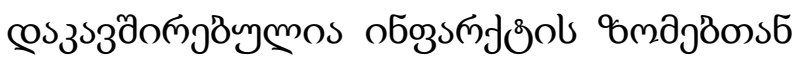

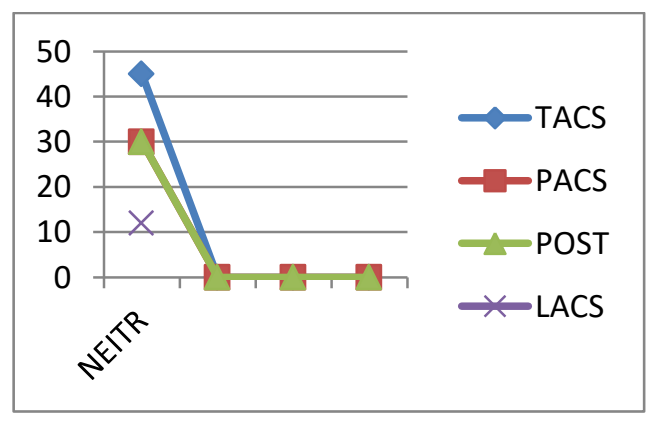

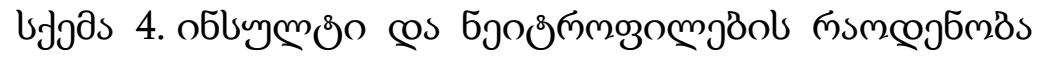

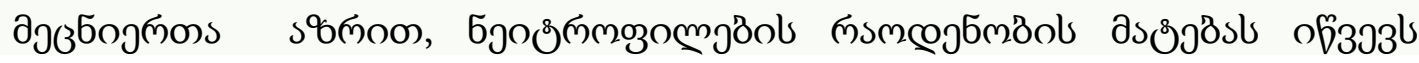

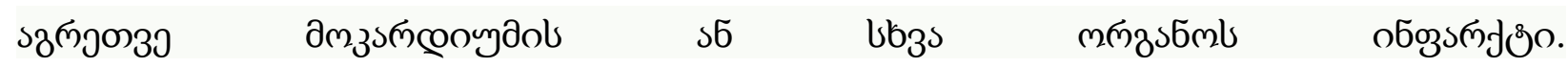

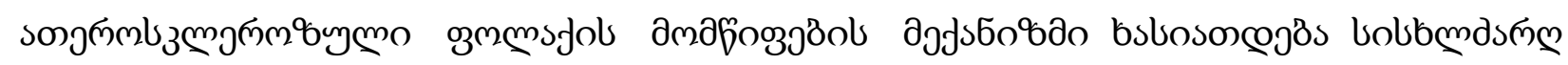

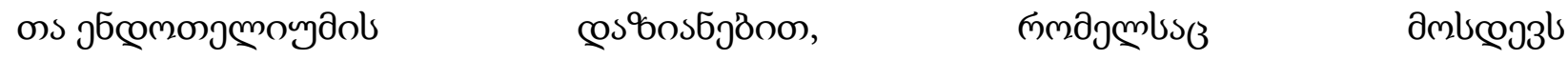

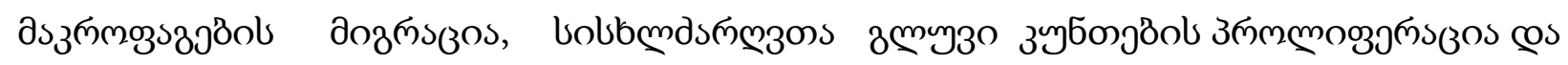

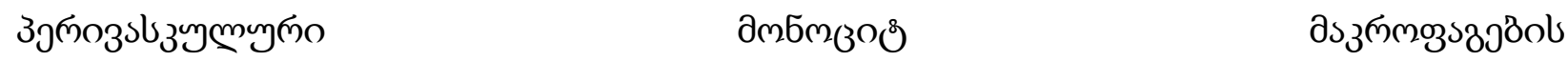




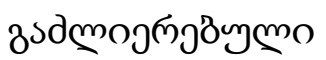

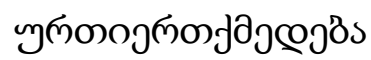

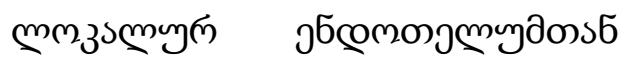

Зпмรболовооо

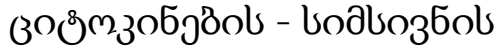

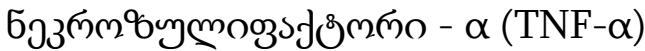

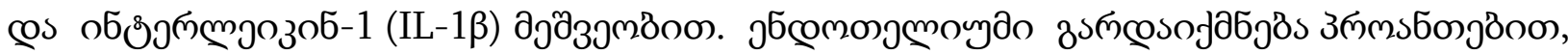

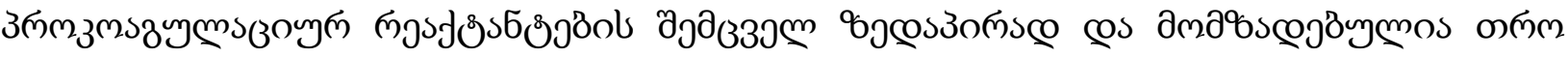

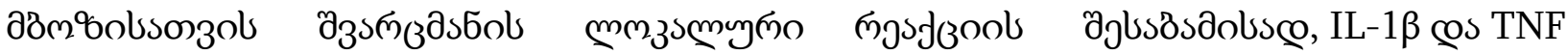

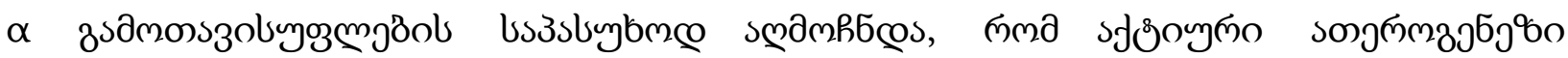

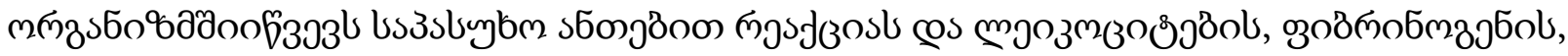

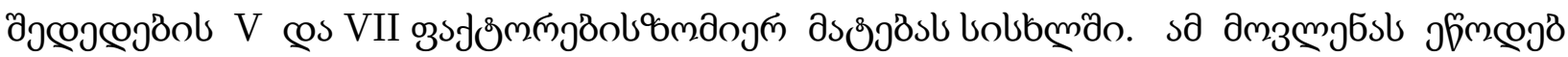

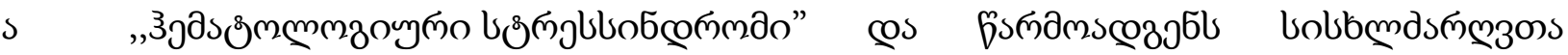

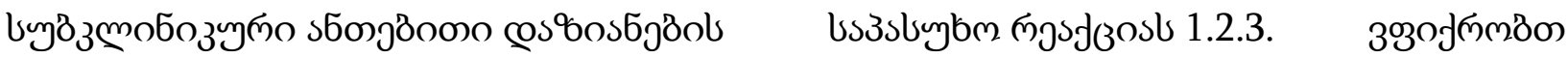

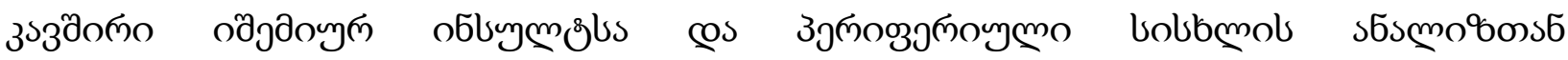

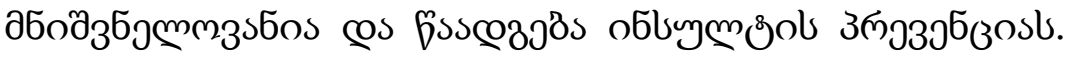

\section{Stroke and leukocytes}

\section{Sh. Vashasdze, M. kekenadze}

\section{Batumi State University after Shota Rustaveli}

Our aim is to study interaction of cerebrovascular diseases and peripheral blood ,to find new methods for prevention of this diseases .Materials and methods. 100 people was taking part in this study, among them 55 was men and 45- women ,aged 18-75 year. They all where diagnosed with brain stroke at acute stage. One hour after stroke amount of neutrophils sharply rises (2-3 times more than norm) and it is directly linked to size of stroke. Because of that when lacunar ischemic stroke have had happened the amount of neutrophils is not raised, however when circulation syndrome is seen the amount of neutrophils sharply rises and it depends on size of stroke. 


\section{Инсульт и лейкоциты}

\section{Ш. Вашасдзе, М. Кекенадзе}

\section{Батумский государственный университет имени Шота Руставели}

Наша цель - изучить взаимодействие цереброваскулярных заболеваний и периферической крови, найти новые методы профилактики этих заболеваний, материалы и методы. В исследовании приняли участие 100 человек, из них 55 мужчин и 45 женщин в возрасте от 18 до 75 лет. У всех диагностирован инсульт в острой стадии. Через час после инсульта количество нейтрофилов резко возрастает (в 2-3 раза больше нормы), что напрямую связано с размером инсульта. Из-за этого при лакунарном ишемическом инсульте количество нейтрофилов не повышается, однако при синдроме кровообращения количество нейтрофилов резко возрастает и зависит от размера инсульта.

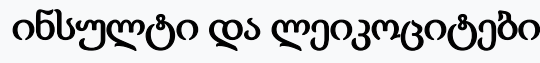

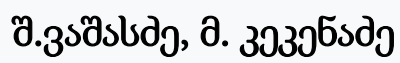

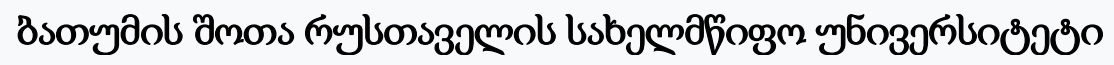

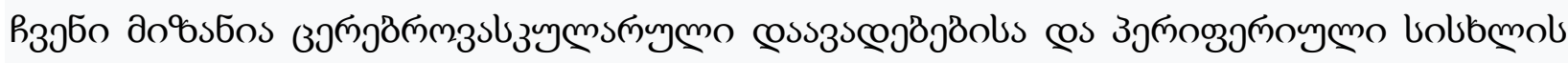

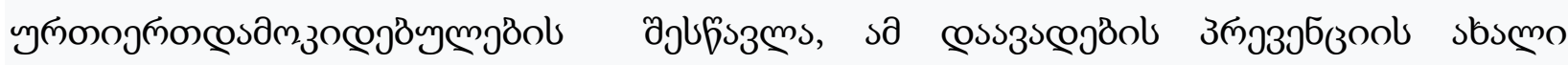

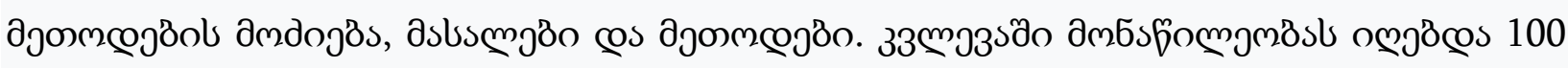

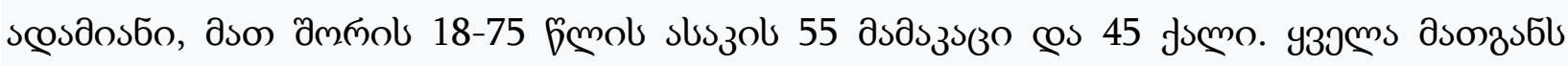

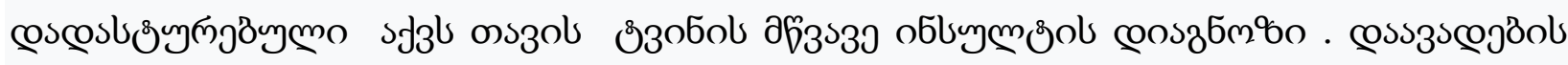

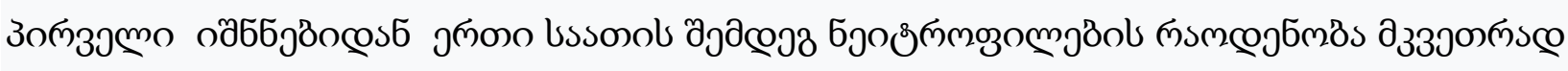

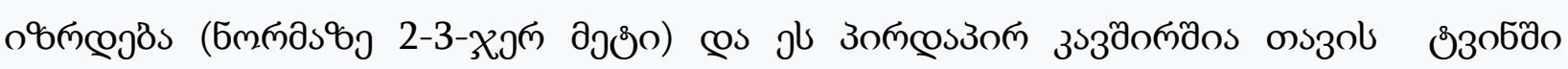

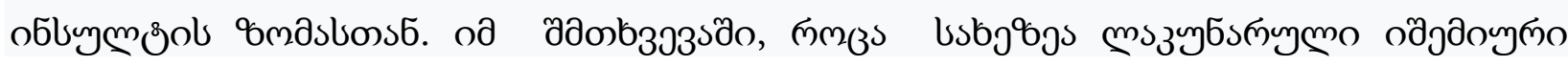




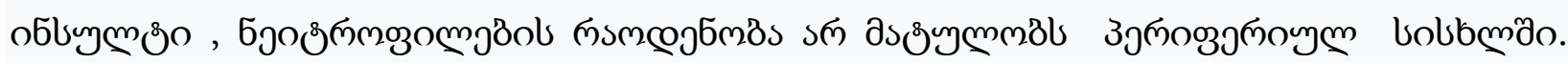

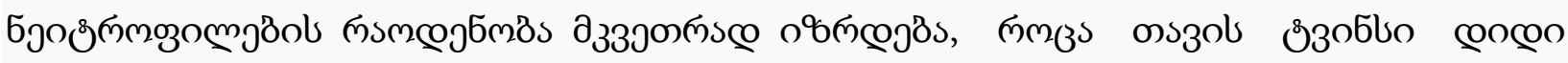

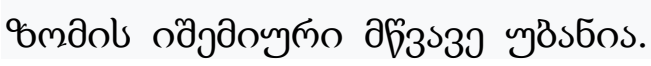

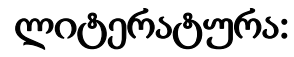

1. Sims NR, Muyderman H (September 2009). "Mitochondria, oxidative metabolism and cell death in stroke". Biochimica et Biophysica Acta 1802 (1): 80 91.doi:10.1016/j.bbadis.2009.09.003. PMID 19751827.

2. Donnan GA, Fisher M, Macleod M, Davis SM (May 2008). "Stroke". Lancet 371 (9624): 1612-23. doi:10.1016/S0140-6736(08)606947.PMID 18468545.

3. Mathers, CD; Boerma, T; Ma Fat, D (2009). "Global and regional causes of death". British medical bulletin 92: 7-32. doi:10.1093/bmb/ldp028. PMID 19776034.

4. National Institute of Neurological Disorders and Stroke. Retrieved 2009-10-24. 